\title{
A CONVENIENT SYNTHESIS OF L-allO-THREONINE
}

Lorenzo WIIllams, Dlane B. Hauze and Madelelne M. Joullie* Department of Chemistry, University of Pennsylvania, Philadelphia, PA 19104-6323, U.S.A.

Abstract: A short and advantageous procedure is described for the preparation of multigram quantities of L-allo-threonine from L-Boc-threonine.

$\beta$-Hydroxyamino acids are an important class of compounds found in many biologically active peptides. Additionally, their potential as chiral building blocks for the synthesis of both natural and unnatural products makes them lucrative targets in themselves. Recently, we became interested in developing a rapid and convenient synthesis of L-allo-threonine as part of a program directed towards the synthesis of a number of oligo and cyclic peptides. Although several methods for the synthesis of either D- or L-allo-threonine have been documented,(1) we became interested In the development of a more convenient protocol from affordable precursors.

The synthesis commenced with the derivatization of the hydroxyl moiety of L-tertbutoxycarbonylthreonine methyl ester (Scheme 1), available by methanolysis of L-tertbutoxycarbonylthreonine. Derivatization of this hydroxyl group was achieved in moderate yield due to the accompanying side product resulting from an elimination reaction. Optimum yields for this transformation were effected by the use of 1.1 equivalents of potassium tert-butoxide. Attempts to form the corresponding mesylate were also plagued by the predominant formation of the elimination product. Cyclization of the $\beta$-toluenesulfonyl derivative to the oxazolidinone 1(2) was accomplished by heating the intermediate in dioxane to afford the cyclized material, determined to be exclusively the cis isomer $\left(\mathrm{J}_{4-5} 8.5 \mathrm{~Hz}\right),(3)$ in quantitative yield. Treatment of oxazolidinone 1 with $6 \mathrm{~N} \mathrm{HCl}$ followed by heating in a sealed tube at $100^{\circ} \mathrm{C}$ for 6 hours afforded L-allo-threonine as the corresponding hydrochloride salt. Liberation of the free amino acid was effected with an ion exchange resin to give L-allo-threonine, which was identical to a sample prepared by the route of Elliott.(1c)

In an attempt to supress the problematic competing elimination involved in the toluenesulfonylation of L-Boc-threonine methyl ester, we considered an alternative pathway. Previously, in our synthesis of $\beta$-hydroxyleucine we had effected a similar conversion through a triflate-mediated pathway.(4) Utilization of this protocol did indeed allow for the formation of the cis oxazolidinone 1 in $\mathbf{4 0} \%$ yield. However, the oxazolidinone was not amenable to purification on silica gel as epimerization led to formation of significant amounts of the more stable trans 
isomer $\left(\mathrm{J}_{4-5} 5 \mathrm{~Hz}\right)$. Thereafter, the crude material was subjected to treatment with $6 \mathrm{~N} \mathrm{HCl}$ to give L-allo-threonine after liberation of the amino acid salt with pyridine as described by Elliott.(1c) Only modest loss of optical purity was detected via this route.(5)<smiles>COC(=O)NCC(C)C</smiles>

(a) KOtBu, TsCl, THF 0-25 ${ }^{\circ} \mathrm{C}(40 \%)$, then $\Delta$, dioxane (100\%); or 2,6-ditBu-4-MePy, $\mathrm{Tf}_{2} \mathrm{O}, \mathrm{CH}_{2} \mathrm{Cl}_{2}, 0^{\circ} \mathrm{C}(40 \%)$. (b) $6 \mathrm{~N} \mathrm{HCl}, 100^{\circ} \mathrm{C}$; Dowex-50W (200-400)/ ref $1 \mathrm{c}(100 \%)$.

\section{Scheme 1}

L-allo-Threonine has been efficiently synthesized from L-Boc threonine. The simplicity of the described processes from readily available starting materials merits particular attention and complements the work of others in this area.

Acknowledgements. Support from NSF (CHE-9218832) is gratefully acknowledged.

(1) (a) V. P. Vassilev, T. Uchiyama, T. Kajimoto, C.-H. Wong, Tetrahedron Lett. 36, 40814084 (1995); (b) M. A. Blaskovich, G. A. Lajoie, ibid. 34, 3837-3840 (1993) and references therein; (c) D. F. Elliott, J. Chem. Soc. 62-68 (1950). As we were interested in obtaining the free amino acid rather than its derivatives, we have only included references to syntheses that reported the free amino acid.

(2) Spectroscopic data for methyl 5(S)-methyl-2-oxazolidinone-4(S)-carboxylate 1: ${ }^{1} \mathrm{H}$ NMR $\left(500 \mathrm{MHz}, \mathrm{CDCl}_{3}\right): \delta 5.41$ (bs, $\left.1 \mathrm{H}\right), 4.93(\mathrm{dq}, \mathrm{J}=8.5,6.5 \mathrm{~Hz}, 1 \mathrm{H}), 4.40(\mathrm{~d}, \mathrm{~J}=8.5 \mathrm{~Hz}$, $1 \mathrm{H}), 3.79(\mathrm{~s}, 3 \mathrm{H}), 1.36(\mathrm{~d}, \mathrm{~J}=6.5 \mathrm{~Hz}, 3 \mathrm{H}) ;{ }^{13} \mathrm{C}$ NMR $\left(125 \mathrm{MHz}, \mathrm{CDCl}_{3}\right): 8169.4,158.3$, 74.3, 58.4, 52.6, 16.3; IR (film): $3370 \mathrm{br}(\mathrm{w}), 2970$ (w), $1741 \mathrm{br}(\mathrm{s}) \mathrm{cm}^{-1}$; $\mathrm{MS}\left(\mathrm{Cl}, \mathrm{NH}_{3}\right)$ : calcd for $\mathrm{C}_{6} \mathrm{H}_{10} \mathrm{NO}_{4}: \mathrm{m} / \mathrm{z}$ 160.0610, found; $160.0609 ; 160(\mathrm{M}+\mathrm{H})^{+}(100), 117(8)$; $[\alpha]_{\mathrm{D}}^{25}-15.8^{\circ}\left(\mathrm{c} 0.5, \mathrm{CHCl}_{3}\right)$.

(3) (a) E. Falb, A. Nudelman, A. Hassner, Synth. Commun. 23, 2839-2844 (1993); (b) S. Futagawa, T. Inui, T. Shiba, Bull. Chem. Soc. Jpn. 46, 3308-3310 (1973).

(4) L.Williams, Z. Zhang, X. Ding, and M. M. Joullie, Tetrahedron Lett. in press.

(5) $[\alpha]_{\mathrm{D}}^{25}+9.0^{\circ}\left(c 3.8, \mathrm{H}_{2} \mathrm{O}\right)\left\{\right.$ lit. $\left.(1 \mathrm{c})+9.3^{\circ}\left(c 3.8, \mathrm{H}_{2} \mathrm{O}\right)\right\}$.

\section{Received June 23, 1995}

